IdeAs

Idées d'Amériques

$7 \mid 2016$

Cinéma et histoire dans les Amériques

\title{
Révolution et commémorations : 1776, 1876, 1976
}

\section{Françoise Coste}

\section{OpenEdition}

\section{Journals}

Electronic version

URL: https://journals.openedition.org/ideas/1630

DOI: 10.4000/ideas.1630

ISSN: 1950-5701

\section{Publisher}

Institut des Amériques

\section{Electronic reference}

Françoise Coste, "Révolution et commémorations : 1776, 1876, 1976", IdeAs [Online], 7 | 2016, Online since 22 July 2016, connection on 19 October 2022. URL: http://journals.openedition.org/ideas/1630 ; DOI: https://doi.org/10.4000/ideas.1630

This text was automatically generated on 19 October 2022

\section{(c) $(1) \odot$}

Creative Commons - Attribution-NonCommercial-NoDerivatives 4.0 International - CC BY-NC-ND 4.0 https://creativecommons.org/licenses/by-nc-nd/4.0/ 


\title{
Révolution et commémorations :
}

\section{$1776,1876,1976$}

\author{
Françoise Coste
}

\section{Introduction}

1 Le fait que les États-Unis soient une nation jeune ne les empêche pas d'avoir un fort sens de leur histoire collective, qui se traduit par une pratique commémorative forte. Dans la conclusion de ses magistraux Lieux de Mémoires, Pierre Nora voit dans ce recours à la commémoration le signe de la nature démocratique d'un pays :

Le phénomène [commémoratif] [...] touche toutes celles des sociétés contemporaines qui se vivent comme historiques, c'est-à-dire fondées sur la liberté instituante des hommes et non pas régies par une volonté divine et qui, à ce titre, ont substitué les grandes dates de leur propre histoire à celles de la commémoration chrétienne ${ }^{1}$.

2 Aux États-Unis, deux « grandes dates » se détachent nettement : la guerre de Sécession (1861-1865) et, surtout, la Révolution du 4 juillet 1776. Celle-ci a particulièrement été célébrée lors du Centennial de 1876 et du Bicentennial de 1976.

Comme le montrent bien Bernard Cottret et Lauric Henneton, dans leur livre Du bon usage des commémorations, ce type d'événement présente une forte polysémie: il se fonde sur "le caractère apparemment cyclique du temps " afin de combiner réflexion sur le passé, message sur le présent, et projection vers l'avenir. Il est également l'occasion pour une société d'exprimer « une stratégie d'affirmation identitaire plus ou moins consciente $»^{2}$. Cette grille d'analyse est très pertinente dans le cas américain. Le Centennial et le Bicentennial peuvent en effet être compris comme des instantanés, des autoportraits de l'Amérique qui, au-delà de la surface festive, en disent beaucoup sur ce que le pays pensait de lui-même, 100 et 200 ans après sa naissance. 


\section{6}

4 Après la Guerre de Sécession, certains Américains se mirent à réfléchir à la meilleure façon de fêter le centenaire de la Révolution, qui se profilait à l'horizon. L'idée germa d'organiser une exposition universelle à Philadelphie, où avait été signée la Déclaration d'Indépendance ${ }^{3}$. La décision fut entérinée par le Congrès en 1871, même si l'essentiel du budget de l'exposition vint de fonds privés ${ }^{4}$. D'emblée, la dimension patriotique de l'exposition devint sa principale raison d'être, dans une visée clairement comparative. Il faut dire que les années d'après-guerre avaient vu l'essor considérable de l'industrie américaine. L'idée était donc de faire du Centennial une vitrine de la nouvelle puissance des États-Unis par laquelle les Américains pourraient, selon les termes de la résolution du Congrès annonçant l'événement, démontrer l'ampleur des «ressources naturelles du pays, son développement et ces avancés dans les arts qui servent l'humanité, par rapport à celles des nations plus anciennes $»^{5}$.

5 La Centennial Exhibition, qui accueillit près de dix millions de visiteurs entre mai en novembre 1876, fut donc conçue comme un temple voué au progrès technologique son nom officiel était « the International Exhibition of Arts, Manufactures and Products of the Soil and Mine $»^{6}$. Le pavillon le plus symbolique était Machinery Hall, où étaient exposées une myriade d'innovations techniques - c'est pendant le Centennial que Edison procéda par exemple à l'une des premières démonstrations publiques du téléphone ${ }^{7}$. Le clou du spectacle y était une gigantesque machine à vapeur, le Corliss steam engine. Ce géant de métal devint le symbole de la supériorité américaine, comme ces lignes de l'écrivain William Dean Howells, parues alors dans The Atlantic Monthly, l'illustrent :

The Corliss engine does not lend itself to description [...]. It rises loftily in the centre of the huge structure, an athlete of steel and iron with not a superfluous once of metal on it; the mighty walking-beams plunge their pistons downward, the enormous fly-wheel revolves with a hoarded power that makes all tremble, the hundred life-like details do their office with unerring intelligence. In the midst of this ineffably strong mechanism is a chair where the engineer sits reading his newspaper. [...] he is like some potent enchanter there, and this prodigious Afreet is his slave who could crush him past all semblance of humanity with his lightest touch. [...] One thinks only of the glorious triumphs of skill and invention; and wherever else the national bird is mute in one's breast, here he cannot fail to utter his pride and content. It would be a barren place without the American machinery. All that Great Britain and Germany have sent is insignificant in amount when compared with our own contributions ${ }^{8}$.

6 L'enthousiasme pour le Centennial n'était cependant pas unanime. Deux groupes en particulier étaient particulièrement conscients de ne pas bénéficier des valeurs démocratiques promises par la Déclaration de 1776, les Noirs et les femmes. Leurs représentants les plus éminents tentèrent de marquer leur colère. Dans un discours resté célèbre, lors du centenaire de l'Abolition Society of Pennsylvania, Frederick Douglass attaqua en 1875 les célébrations à venir: "The Centennial of seventy-six stands for patriotism; ours stands for philanthropy. One stands for nationality; the other stands for universal humanity. One stands for what is transient; the other stands for what is permanent. $»^{9}$. De leur côté, les militantes de la National Woman Suffrage Association, amenées par Susan B. Anthony, organisèrent une contre-manifestation à Philadelphie, le 4 juillet 1876. Et pourtant, même ces voix discordantes ne surent échapper à l'élan patriotique : bien qu'il n'ait pas eu le droit de prendre la parole, Douglass accepta de 
rejoindre la tribune officielle, aux côtés du président Grant, lors de la cérémonie d'ouverture de la Centennial Exhibition ${ }^{10}$; quant aux militantes féministes, elles semblèrent presque s'excuser de troubler la liesse nationale, tant elles tinrent à insister sur leur fierté patriotique avant de défendre leur cause :

While the nation is buoyant with patriotism, and all hearts are attuned to praise, it is with sorrow we come to strike the one discordant note. [...] Surveying America's Exposition, surpassing in magnificence those of London, Paris, and Vienna, shall we not rejoice at the success of the youngest rival among the nations of the world? [...] And we do rejoice, in the success thus far, of our experiment of self-government. [...] Yet we cannot forget, even in this glad hour, that while all men of every race, and clime, and condition, have been invested with the full rights of citizenship, under our hospitable flag, all women still suffer the degradation of disfranchisement ${ }^{11}$.

7 Le centenaire de la Révolution laisse ainsi une impression plutôt réussie. S’il suscita certes des critiques, ces dernières ne trouvèrent pas suffisamment d'écho pour troubler la fierté du jeune pays en train de conquérir le monde.

\section{6}

8 Le contexte du Bicentennial de 1976 est, lui, très différent. Du début à la fin, la commémoration se déroula en effet dans l'ombre de la guerre du Vietnam. Ainsi, quand il signa en 1966 la loi créant l'organisme en charge de l'organisation du bicentenaire, l'American Revolution Bicentennial Commission (ARBC), le président Johnson prit soin de souligner le parallèle suivant: «Today, the Vietnamese people are fighting for their freedom in South Vietnam. We are carrying forward our great heritage by helping to sustain their efforts $»^{12}$. Les dix années suivantes furent tumultueuses, à la fois pour les États-Unis et pour l'ARBC.

Pendant que la défaite militaire se profilait en Asie, les débats sur les commémorations de 1976 prirent un tour compliqué. La Commission dut abandonner les deux projets qu'elle avait initialement envisagés : une nouvelle exposition universelle à Philadelphie et la construction d'un «Bicentennial Park » dans chaque état du pays. Dans les deux cas, c'est leur prix prohibitif qui précipita l'échec de ces idées ${ }^{13}-$ on était loin de l'esprit triomphant de 1876. Pire encore, au début des années 1970, l'ARBC se retrouva sous le feu nourri des critiques: alors qu'une commission d'enquête du Congrès souligna son inaction, elle fut aussi accusée d'être trop proche de l'administration Nixon, de ne pas travailler en tandem avec les autorités locales et d'ignorer les demandes des minorités ethniques ${ }^{14}$.

Devant ce fiasco, l'ARBC fut dissolue en 1973 et remplacée l'année suivante par l'American Revolution Bicentennial Administration (ARBA). La feuille de route de cette nouvelle instance prit en compte les attaques à l'encontre de l'ARBC. Décision fut prise d'intégrer plus de voix noires parmi ses membres et de complètement décentraliser la commémoration ${ }^{15}$. Contrairement à 1876 , la célébration n'aurait pas de vaisseau amiral dans un endroit précis, afin de pouvoir associer le plus grand nombre d'Américains à l'événement. In fine, des festivités (feux d'artifice, discours, création d'un musée ambulant dans un «Freedom Train »...) furent organisées dans plus de 12000 «Bicentennial communities $»^{16}$. Systématiquement, les organisateurs tentèrent de mobiliser tous les groupes sociaux et raciaux du pays, comme les femmes et les immigrés ${ }^{17}$. 
11 Le souci d'ouvrir le plus possible la commémoration était un geste profondément politique. Les responsables de l'ARBA et le président Ford avaient conscience du contexte délétère dans lequel le Bicentennial allait prendre place. La défaite au Vietnam représentait une blessure à l'orgueil américain difficilement susceptible de générer l'enthousiasme. Quant au Watergate, il avait mis à mal la confiance du peuple dans le gouvernement fédéral, et la personne même du président Gerald Ford était l'incarnation de la faillite des institutions dans les années $1970^{18}$. L'humeur américaine était donc complexe, d'où des initiatives alternatives, comme la création en 1971 de la People's Bicentennial Commission ( $\mathrm{PBC}$ ) par un militant d'extrême-gauche Jeremy Rifkin. Le but du PBC était d'organiser un bicentenaire participatif, une commémoration populaire où les Américains redécouvriraient les racines radicales de la Révolution ${ }^{19}$. Dans cette atmosphère de morosité et de colère, l'administration Ford et l'ARBA voyaient dans une mobilisation large et diversifiée le meilleur moyen de faire renouer le peuple avec son patriotisme traditionnel. Le Bicentennial pouvait ainsi devenir une formidable opportunité : des commémorations partagées et réussies permettraient de tourner la page du tumulte des années 60 et 70. Le but de l'ARBA était en ce sens fondamentalement conservateur, comme le reconnut John Warner, son président: « [Americans will] honor the great men who forged and then steered a nation so strong and so flexible that one revolution has proved enough $»^{20}$.

12 Finalement, les célébrations de 1976 parvinrent à imposer un message positif sur les États-Unis. Comme en 1876, les contre-manifestations s'avérèrent en effet, au bout du compte, plutôt futiles, les critiques ne pouvant s'empêcher d'exprimer leur admiration pour les héros traditionnels de la Révolution. Un groupe de militants noirs appela par exemple ses membres à célébrer «la philosophie et les aspirations des premiers révolutionnaires américains comme Jefferson, Paine et Sam Adams $»^{21}$; même les tracts distribués par la PBC retombaient dans une vision conventionnelle de 1776, articulée autour de Tom Paine, du Boston Massacre et de la Boston Tea Party, de Patrick Henry et Jefferson, de Lexington et Concord ${ }^{22}$. Malgré les craintes et les tensions, le Bicentennial, comme le Centennial un siècle auparavant, se conclut sur un relatif consensus commémoratif, comme si la force d'attraction de la Révolution était toujours irrésistible.

13 Il est d'ailleurs intéressant de remarquer que, aujourd'hui, la perception du 4 juillet 1776 semble bien plus apaisée que par le passé. Les déclarations du président Obama lors d'une cérémonie à la Maison Blanche, pour le $240^{\mathrm{ème}}$ anniversaire de la Déclaration d'Indépendance, le 4 juillet 2016, illustrent bien cette évolution. Obama a certes rappelé que les promesses de la Révolution n'avaient pas encore été toute tenues:

[The $4^{\text {th }}$ of July] involves us recognizing that there are still people in this country who are going hungry -- and they're not free because of that. There are still people in this country who can't find work -- and freedom without the ability to contribute to society and put a roof over your head or look after your family, that's not yet what we aim for (Obama B., 2016).

Mais c'est un ton résolument et fièrement patriotique qui, globalement, a guidé le président ce soir-là. Evoquant avec émotion «the American family ", il a comparé les États-Unis à « un miracle ». Et quinze ans après le 11 septembre, la dimension militaire de ce « miracle » est frappante. Obama a ainsi rappelé que la Révolution était née d'une guerre ( $[$ [...] how incredibly lucky we are that people, generations ago, were willing to take up arms and fight for our freedom. ») et que la vie même du pays tenait, encore aujourd'hui, à sa puissance militaire : «We all know that our freedoms are dependent 
on an incredible group of men and women in uniform and their families who look out for us every single day. $»^{23}$. Les leçons du 4 juillet 1776 résonnent encore donc avec pertinence au XXI ${ }^{\text {ème }}$ siècle.

\section{NOTES}

1. Pierre Nora, Pierre, Les lieux de mémoire (Paris, Quarto Gallimard, 1997), p.4687-4688.

2. Bernard Cottret et Henneton, Lauric, «La commémoration, entre mémoire prescrite et mémoire proscrite», in Bernard Cottret et Lauric Henneton (Dir.), Du bon usage des commémorations, Histoire, mémoire et identité, XVIe-XXIe siècle (Rennes, Presses Universitaires de Rennes, 2010), p. 14, 15.

3. Tout le monde n'était cependant pas convaincu : de nombreux Représentants et Sénateurs se montrèrent très réticents à organiser une telle manifestation, la jugeant trop onéreuse pour certains, inutiles pour d'autres (une critique venant tout particulièrement des élus des États ne faisant pas partie des 13 colonies et qui ne se sentaient donc pas directement concernés par les événements du 4 juillet 1776). De plus, le centenaire venant si peu de temps après la Guerre de Sécession, les États du Sud refusèrent de participer à l'exposition (Faith K. Pizor, « Preparations for the Centennial Exhibition of 1876 ", Pennsylvania Magazine of History and Biography, Vol. 94, No. 2, April 1970, p.214-215, 216-217. https://journals.psu.edu/pmhb/article/view/42622, page consultée le 13 juin 2016 ; Harold M. Hyman, « Review: Observations Observed, or Centennials Revisited", Reviews in American History, Vol. 1, No. 2, Jun. 1973, p.229; Lyn Spillman, "When Do Collective Memories Last? Founding Moments in the United States and Australia ", Social Science History, Vol. 22, No. 4, Winter 1998, p. 454-455).

4. John Bodnar, Remaking America, Public Memory, Commemoration, and Patriotism in the Twentieth Century, Princeton (Princeton University Press, 1994), p.29; Spillman, op.cit., p. 454.

5. Cité dans Sean Dennis Cashman, America in the Gilded Age, From the Death of Lincoln to the Rise of Theodore Roosevelt (New York, New York University Press, 1993), p.6,8.

6. Hélène Quanquin, «1776-1876: Un autre 4 Juillet, Commémorations afro-américaines et féministes ", in Bernard Cottret et Lauric Henneton (Dir.), Du bon usage des commémorations, Histoire, mémoire et identité, XVIe-XXIe siècle (Rennes, Presses Universitaires de Rennes, 2010), p. 122.

7. Ethan Robey, «Review: Bruno Giberti, Designing the Centennial: A History of the 1876 International Exhibition in Philadelphia », Isis, Vol. 95, No.2, June 2004, p. 304; Cashman, op.cit., p.22.

8. William Dean Howells, « A Sennight of the Centennial », The Atlantic Monthly, July 1876, p.96, http://ebooks.library.cornell.edu/cgi/t/text/pageviewer-idx?

c=atla;cc=atla;rgn=full\%20text;idno=atla0038-1;didno=atla0038-1;view=image;seq=0098;node=atla0038-1\%3A13, page consultée le 13 juin 2016.

9. Frederick Douglass, "Address at the Centennial Celebration of the Abolition Society of Pennsylvania », 1875, https://www.loc.gov/resource/mfd.23002/?sp=4, page consultée le 13 juin 2016.

10. Philip S. Foner, «Black Participation in the Centennial of 1876 ", Phylon, Vol. 39, No. 4, $4^{\text {th }}$ Quarter 1978, p. 283-284. 
11. National Woman Suffrage Association, «Declaration and Protest of the Women of the United States by the National Woman Suffrage Association », 4 juillet 1876, http://memory.loc.gov/rbc/ rbpe/rbpe16/rbpe160/16000300/001dr.jpg, page consultée le 13 juin 2016.

12. Lyndon Baines Johnson, "Letter to the President of the Senate and to the Speaker of the House Proposing the Establishment of an American Revolution Bicentennial Commission ", 10 mars 1966, Public Papers of the Presidents of the United States (Washington, United States Government Printing Office, 1967), p.121.

13. Bodnar, op.cit., p.230-231.

14. Bodnar, op.cit., p.231; Jill Lepore, The Whites of their Eyes, The Tea Party's Revolution and the Battle over American History (Princeton, Princeton University Press, 2010), p.65.

15. David Ryan, «Re-enacting Independence through Nostalgia - The 1976 US Bicentennial after the Vietnam War ", Forum for Inter-American Research, Vol. 5.3, December 2012, http:// interamericaonline.org/volume-5-3/ryan/, page consultée le 13 juin 2016.

16. Bodnar, op.cit., p.231-233; Spillman, op.cit., p.457; Ryan, op.cit..

17. Spillman, op.cit., p.460, 466.

18. Ryan, op.cit.

19. Bodnar, op.cit., p.234-235; Lepore, op.cit., p.65. La PBC était également extrêmement critique de la dimension commerciale du Bicentennial; il faut dire que les difficultés financières de l'ARBA l'avaient poussé à signer de nombreux contrats de sponsoring et de merchandising avec de grandes entreprises privées, comme Pepsico, General Motors ou American Airlines (Bodnar, op.cit., p.233, 235).

20. Bodnar, op.cit., p.227, 234.

21. Traduit par l'auteur.

22. Spillman, op.cit., p. 467.

23. Barack Obama, «Remarks by the President at Fourth of July Celebration », The White House, July 4, 2016, https://www.whitehouse.gov/the-press-office/2016/07/04/remarks-presidentfourth-july-celebration, page consultée le 14 juillet 2016.

\section{AUTHOR}

\section{FRANÇOISE COSTE}

Françoise Coste est agrégée d'anglais, ancienne élève de l'ENS Fontenay-Saint Cloud et docteur en civilisation américaine. Elle est Maître de Conférences à l'Université de Toulouse - Jean Jaurès et a publié de nombreux articles sur l'histoire politique des États-Unis. Sa biographie de Ronald Reagan, Reagan, parue chez Perrin, a reçu le prix de la biographie politique de l'année en 2015. 